\title{
Effect of Hormonal Contraceptive on Sexual Life, Body Mass Index, Skin Health, and Uterine Bleeding, in Women of Reproduction Age in Jombang, East Java
}

\author{
Esti Pratiwi Yosin'), Ambar Mudigdo², Uki Retno Budihastuti3) \\ ${ }^{1)}$ School of Health Sciences Insan Cendekia Medika, Jombang \\ 2)Faculty of Medicine, Sebelas Maret \\ 3)Departement of Obstetrics and Gynecology, Dr.Moewardi Hospital, Surakarta
}

\begin{abstract}
Background: Injection hormonal contraceptive can be distinguished into depomedroxyprogesterone acetate (DMPA) and combination. DMPA injection is administered in single dose of $150 \mathrm{mg} / \mathrm{mL}$ intramuscular every 12 week. It was hypothesized that DMPA injection resulted inadvertent effect such as lowered sexual life quality, increased body mass index, lowered quality of skin health, and abnormal uterine bleeding. This study aimed to examine the effects of DMPA injection on sexual life, body mass index, skin health, and abnormal uterine bleeding.

Subjects and Method: This was observational analytical study with retrospective cohort design. This study was conducted in Jombang, East Java. A total sample of 149 women of reproductive age consisting of 99 DMPA injection contraceptive users and 50 non hormonal contraceptiveusers was selected for this study, by stratified random sampling. The dependent variables were sexual life quality, body mass index (BMI), skin health, and uterine bleeding. The independent variable was DMPA injection contraceptive use and age. The data were collected by a set of questionnaire. Sexual life quality was measured by female sexual function index (FSFI). The data were analyzed by multiple logistic regression.
\end{abstract}

Results: Hormonal contraceptive use $(\mathrm{OR}=20.17$; 95\% $\mathrm{CI}=6.62$ to $61.42 ; \mathrm{p}<0.001)$ and age $30-35$ years old $(\mathrm{OR}=17.51 ; 95 \% \mathrm{CI}=5.74$ to $53.38 ; \mathrm{p}<0.001)$ increased the risk of low quality of sexual life. Age 30-35 years old lowered $(\mathrm{OR}=0.16 ; 95 \% \mathrm{CI}=0.07$ to $0.36 ; \mathrm{p}<0.001)$ low quality of skin health. Hormonal contraceptive use $(\mathrm{OR}=4.25 ; 95 \% \mathrm{CI}=1.95$ to $9.30 ; \mathrm{p}<0.001)$ increased the risk of low quality of skin health.

Conclusion: Hormonal contraceptive use and age 30-35 years increase the risk of low quality of sexual life. Age 30-35 years old decreases low quality of skin health but hormonal contraceptive use increases the risk of low quality of skin health.

Keywords: hormonal contraceptive injection, sexual life, body mass index, uterine bleeding

\section{Correspondence:}

Esti Pratiwi Yosin. School of Health Sciences Insan Cendekia Medika, Jombang, East Java. Email:estipratiwi77@gmail.com.

\section{BACKGROUND}

Indonesia's population growth rate in 2015 is alarming because it reaches $1.49 \%$ or around 4.5 million annually. This growth rate will be even more worrying if the birth is not qualified, the actual population must drop to at least $1.1 \%$, hampered by several problems faced by the development of population and family planning, including the still high population growth compared to the conditions that will be achieved by 1.1\%; there is still a high total birth rate (TFR) compared to an ideal condition of 2.1 children per woman of reproductive age and disparity (gap) between provinces, between rural-urban areas, and between socio-economic groups.

Faster population growth in Indonesia needs to get serious attention from the parties concerned, not only from 
government agencies that handle it, but also from the society. If you do not get support from the community, especially couples of childbearing age, then the program of the National Population and Family Planning Board specifically for the independent family planning movement will not be achieved. If this happens, then the faster growth cannot be avoided by the Indonesian people, which has a negative impact on economic growth, increasingly narrow employment, etc.

The lack of success of the selfplanning family movement is most likely due to the low and insignificant increase in contraceptive use (CPR), and there are still disparities between provinces, regions and levels of welfare; still less effective in the use of long-term contraceptive methods such as intrauterine device / IUD, implants, female and male surgery methods (MOW and MOP), and more use of contraception for short periods such as injections and pills; still high drop-out rates (including failures and complications) in the use of short-term contraceptives that most acceptors use; the low participation of men in family planning.

According to Data Achievement of Estimated Public Demand (PPM), active family planning participants in 2015 were 29,714,498 participants with details of condom users of condoms amounting to 1,099,380 participants (3.70\%), MOW amounting to $1,663,930$ participants (5.60\%), injections of $15,988,541$ participants (53.81\%), IUD was 2,020,490 participants $(6.80 \%)$, MOP was 148,560 participants (0.50\%), implants were 2,256,727 participants (9.59\%) and pills were 6,536,870 participants (22\%). In East Java today many fertile women (WUS) use contraception in the form of injectable birth control. Data collected at the East Java National Population and Family Planning
Board (BKKBN) showed the use of injectable contraceptives reached 443,110 participants (59.49\%), pill amounting to 156,384 participants (21\%), implant amounting to 63,918 participants (8.58\%), condoms amounting to 22,748 participants (3.05\%), IUD amounting to 45,809 participants (6.15\%), MOW amounting to 12,864 participants (1.73\%).

According to Everett (2008), the effectiveness of injectable contraception between $99 \%$ and $100 \%$ in preventing pregnancy, while according to Uliyah (2008) failure in the use of injectable contraceptives is only about 0.3 pregnancies from 100 users in the first year including DMPA (depot medroxcyprogesteroneacetate) and combination. DMPA injections contain a medroxcyprogesterone acetate depot given in a single injection of $150 \mathrm{mg} / \mathrm{ml}$ intramuscularly (IM) every 12 weeks (Uliyah, 2010). But the side effects of using injectable contraception for a long time according to Everett (2008) can cause irregular bleeding, amenorrhea, late return to fertility to one year, depression, increased body weight, and osteoporosis.

According to Everett (2008), the effectiveness of injectable contraception is between $99 \%$ and $100 \%$ in preventing pregnancy, while according to Uliyah (2008), failure in the use of injectable contraceptives is only about 0.3 pregnancies from 100 users in the first year which are DMPA (depot medroxcyprogesterone acetate) and combination. DMPA injections contain a medroxcyprogesterone acetate depot given in a single injection of $150 \mathrm{mg} / \mathrm{ml}$ intramuscularly (IM) every 12 weeks (Uliyah, 2010). But the side effects of using injectable contraception for a long time according to Everett (2008), can cause irregular bleeding, amenorrhea, late return to fertility to one year, depression, increased body weight, and osteoporosis. 
A study by Murniawati and Endang (2012), the subjects of the old study using new categories amounted to 11 people (100\%) experienced an increase in body weight of 8 people $(72.7 \%)$ and those who did not rise by 3 people (27.3), while the research subjects were in the old category 21 people (100\%), gained 21 people (100\%). According to Irianto (2014), the occurrence of weight gain is likely because the hormone progesterone makes it easier to change carbohydrates and sugar into fat, so that the fat under the skin increases. In addition, the hormone progesterone also causes appetite to increase and decrease physical activity, as a result, of the use of injections can cause weight gain.

At the time of the woman before menstruation, they usually will experience some problems, one of them is the appearance of acne on the face, this is due to an increase in the hormone progesterone which makes the skin produce excessive oil, so it can support the onset of acne due to accumulation of fat in the tissue. According to Irianto (2014), hormonal changes caused by the use of injectable contraception can cause some skin disorders such as the onset of acne.

Based on preliminary studies by interviewing in Jombang Subdistrict, Jombang Regency, women of reproductive age (WUS) who use injectable contraception $>1$ year, 20 study subjects experienced sexual dysfunction in the form of 5 libido decreases (25\%), this is because they often feel pain during intercourse and ultimately reduce the sexual desire or arousal, and that is associated with an average weight gain of $2.7 \mathrm{~kg}$ for the first year of use amounting to6 people (30\%), while those who experience skin disorders, such as facial acne due to use DMPA contraception was 7 people (35\%), while the remaining 2 people (10\%) did not experience side effects because of the length of use $<1$ year.

The mitigation of side effects caused by the use of injectable contraceptives is by providing counseling to prospective $\mathrm{KB}$ acceptors about the disadvantages and benefits of using contraceptive injections, while for participants of the old family planning acceptors who used injectable contraceptives and experienced side effects such as sexual dysfunction in the form of decreased libido, weight gain and skin health, namely zits need to stop the use of injectable contraceptives and consult health professionals or clinics.

\section{SUBJECTS AND METHOD}

This was an analytic observational study with a cross sectional design. The study was conducted in Jombang, East Java, from June to August 2016. The population of this study were all women of childbearing age who used injectable contraceptive contraceptives in Jombang District amounting to 9,072 people. A sample of 99 women reproductive age was selected for this study by stratified random sampling. Data on sexual quality was measured by female sexual function index (FSFI). The other variables were measured by questionnaire and analyzed by a multiple logistic regression.

RESULTS
1. Univariate analysis
The results of the description of Table 1 show
that the characteristics of the research
subjects were mostly $30-35$ years old for
women of childbearing age amounting to 85
people (57\%), most of them were more than
high school education amouting to 136
people (91.3\%) and worked amounting to 90
people (90.4\%).


Table 1. The frequency distribution of study subject characteristics

\begin{tabular}{lcc}
\hline \multicolumn{1}{c}{ Characteristics } & n & \% \\
\hline Age & 64 & 43.0 \\
20-29 years & 85 & 57.0 \\
30-35 years & & \\
Education & 13 & 8.7 \\
Primary school (< SHS) & 136 & 91.3 \\
Secondary school ( $\geq$ SHS) & & \\
Occupation & 59 & 39.6 \\
Not working & 90 & 60.4 \\
Working &
\end{tabular}

Based on the results in Table 2, it is known that most are hormonal contraceptives which consisted of 81 people (54.4\%), sexual life has 86 people (57.7\%), 96 people gain weight (64.4\%), acne skin health of 93 people (62.4\%), and abnormal bleeding is 89 people (40.3\%).

\section{Table 2. Samples Description}

\begin{tabular}{|c|c|c|}
\hline Variable & $\mathbf{n}$ & $\%$ \\
\hline \multicolumn{3}{|l|}{ Type of Contraception } \\
\hline Non Hormonal & 68 & 45.6 \\
\hline Hormonal & 81 & 54.4 \\
\hline \multicolumn{3}{|l|}{ Sexual Life } \\
\hline No disorder & 63 & 42.3 \\
\hline With disorder & 86 & 57.7 \\
\hline \multicolumn{3}{|l|}{ Body mass index } \\
\hline Not gain & 53 & 35.6 \\
\hline Gain & 96 & 64.4 \\
\hline \multicolumn{3}{|l|}{ Skin Health } \\
\hline No acnes & 56 & 37.6 \\
\hline Acnes & 93 & 62.4 \\
\hline \multicolumn{3}{|l|}{ Abnormal Uterine Bleeding } \\
\hline Normal & 60 & 59.7 \\
\hline Abnormal & 89 & 40.3 \\
\hline
\end{tabular}

Table 3. Chi-square test of the relationship between age and type of injection contraception with quality disorders of sex life

\begin{tabular}{|c|c|c|c|c|c|c|}
\hline \multirow[b]{2}{*}{ Variable } & \multicolumn{2}{|c|}{ Sexual Life } & \multirow[b]{2}{*}{ OR } & \multicolumn{2}{|c|}{$95 \%$ CI } & \multirow[b]{2}{*}{$\mathbf{p}$} \\
\hline & No disorders & With disorder & & $\begin{array}{l}\text { Lower } \\
\text { Limit }\end{array}$ & $\begin{array}{l}\text { Upper } \\
\text { Limit }\end{array}$ & \\
\hline Age & & & & & & \\
\hline $\begin{array}{l}\text { 20-29years } \\
30-35 \text { years }\end{array}$ & $\begin{array}{l}44(68.8 \%) \\
19(22.4 \%)\end{array}$ & $\begin{array}{l}20(31.3 \%) \\
66(77.6 \%)\end{array}$ & 7.64 & 3.66 & 15.93 & $<0.001$ \\
\hline $\begin{array}{l}\text { Type of } \\
\text { contraception }\end{array}$ & & & & & & \\
\hline $\begin{array}{l}\text { Non hormonal } \\
\text { Hormonal }\end{array}$ & $\begin{array}{l}47(69.1 \%) \\
16(19.8 \%)\end{array}$ & $\begin{array}{l}21(30.9 \%) \\
65(80.2 \%)\end{array}$ & 9.09 & 4.29 & 19.26 & $<0.001$ \\
\hline
\end{tabular}


There was a positive and significant relationship between types of contraception and skin health in women with reproductive age $(\mathrm{OR}=3.03 ; 95 \% \mathrm{CI}=1.52$ to 6.03 ; $\mathrm{p}<0.001)$.

Analysis on variables of age, type of contraception, abnormal uterine bleeding, and bady mass index were conducted using the Pearson product moment test.

Table 5 presents a the bivariate analysis of age with abnormal uterine bleeding, obtained Pearson correlation (r)

Table4. Chi-square test of the relationship between age and type of injection contraception with skin health

\begin{tabular}{|c|c|c|c|c|c|c|}
\hline \multirow{2}{*}{ Variable } & \multicolumn{2}{|c|}{ Skin Health } & \multirow{2}{*}{ OR } & \multicolumn{2}{|c|}{ 95\% CI } & \multirow[b]{2}{*}{ p } \\
\hline & No disorders & Disorders & & Lower Limit & Upper Limit & \\
\hline Age & & & & & & \\
\hline $20-29$ & $12(18.8 \%)$ & $52(81.3 \%)$ & 0.21 & 0.10 & 0.45 & $<0.001$ \\
\hline 30-35 years & $44(51.8 \%)$ & $41(48.2 \%)$ & & & & \\
\hline Type of Contrace & & & & & & \\
\hline $\begin{array}{l}\text { Non hormonal } \\
\text { Hormonal }\end{array}$ & $\begin{array}{l}35(51.5 \%) \\
21(25.9 \%)\end{array}$ & $\begin{array}{l}33(48.5 \%) \\
60(74.1 \%)\end{array}$ & 3.03 & 1.52 & 6.02 & $<0.001$ \\
\hline
\end{tabular}

Table 5. Pearson product moment test of relationship between age and hormonal contraception with abnormal uterine bleeding

\begin{tabular}{clccc}
\hline \multicolumn{1}{c}{ Variable } & & r & P \\
\hline Dependent & \multicolumn{1}{c}{ Independent } & & 0.007 \\
Abnormal uterine bleeding & The age of 30-35 years & & 0.22 & $<0.001$ \\
\multirow{2}{*}{ Body mass index } & Hormonal & & 0.71 & $<0.001$ \\
& The age of 30-35 years & 0.53 & $<0.001$ \\
\hline
\end{tabular}

The relationship of age variables with body mass index, the pearson correlation (r) was 0.53 and $\mathrm{p}<0.001$. This shows that there is a positive and significant relationship between age and abnormal uterine bleeding in women of childbearing age. The relationship of the variable type of contra- value of 0.22 with $\mathrm{p}=0.007$. This shows that there is a positive and significant relationship between age and abnormal uterine bleeding in women of childbearing age.

In the variable type of contraception with abnormal uterine bleeding, a Pearson correlation (r) value was 0.71 with $\mathrm{p}<0.001$. This shows that there is a positive and significant relationship between types of contraception and abnormal uterine bleeding in women of childbearing age.

Table 6. Results of logistic regression analysis of age and hormonal contraception with impaired quality of sexual life at women of childbearing age

\begin{tabular}{lcccc}
\hline \multirow{2}{*}{ Independent Variable } & \multirow{2}{*}{ OR } & \multicolumn{2}{c}{ CI (95\%) } & \multirow{2}{*}{ p } \\
\cline { 3 - 4 } & & Lower Limit & Upper Limit & \\
\hline Age & 17.51 & 5.74 & 53.38 & $<0.001$ \\
Hormonal contraception & 20.17 & 6.62 & 61.42 & $<0.001$ \\
N Observation $\quad=149$ & & & & \\
-2 log likelihood $\quad=125.336$ & & & & \\
Nagelkerke R-Square & $=0.546$ & & & \\
\hline
\end{tabular}


Table 6 shows that there is a statistically significant relationship between age and quality disorders of sexual life experiencing disturbances $(\mathrm{OR}=17.51 ; 95 \% \mathrm{CI}=5.75$ to 53.39; p<0.001). The older people are, the more (17.52 times) they experience sexual health problems. There was a statistically significant relationship between types of contraception with quality disorders of sexual life experiencing disturbances $(\mathrm{OR}=20.17$; $\mathrm{CI}$
95\% 6.62 to $61.42 ; \mathrm{p}<0.001)$. Hormonal contraception is 20.17 times having a disruption in sexual life. Nagelkerke's R Square value is $54.6 \%$, this indicates that the variability of the dependent variable that can be explained by the independent variable is $54.6 \%$ while the remaining $45.4 \%$ is explained by the variability of other variables outside the two independent variables examined.

Table 7. The results of logistic regression analysis between age, hormonal contraception, and skin health disorders in women of childbearing age

\begin{tabular}{lcccc}
\hline \multicolumn{1}{c}{ Independent Variabel } & \multirow{2}{*}{ OR } & \multicolumn{2}{c}{$\mathbf{9 5 \% \text { CI }}$} & \multirow{2}{*}{$\mathbf{p}$} \\
\cline { 3 - 4 } & & Lower Limit & Upper Limit & $<0.001$ \\
The age of 30-35 years & 0.16 & 0.07 & 0.36 & $<0.001$ \\
Hormonal Contraception & 4.25 & 1.95 & 9.30 & \\
N Observation=149 & & & \\
-2 log likelihood= 104.95 & & & \\
Nagelkerke R-Square= 26\% & & & \\
\hline
\end{tabular}

Table 7 shows the results of logistic regression analysis, there is a statistically significant relationship between age with skin health experiencing acne $(\mathrm{OR}=0.16$; 95\% CI $=0.07$ to $0.36 ; \mathrm{p}<0.001)$. The older the age in, the higher the probability of experiencing acnes is (0.16 times). There was a statistically significant relationship between types of contraception with skin health experienced by jewels ( $\mathrm{OR}=4.25 ; 95 \% \mathrm{CI}=1.95$ to 9.30; $\mathrm{p}<0.001)$. Type of hormonal contraception 20.16 times experiencing acne. Nagelkerke's $\mathrm{R}$ Square value is 0.26 , this indicates that the variability of the dependent variable that can be explained by the independent variable is $26 \%$ while the remaining $74 \%$ is explained by the variability of other variables outside the two independent variables examined.

Table 8. Linear regression between age and hormonal contraception with abnormal uterine bleeding in women of childbearing age

\begin{tabular}{lccc}
\hline \multicolumn{1}{c}{ Independent Variable } & B & SE & p \\
\hline Constant & 6.09 & 0.21 & $<0.001$ \\
Hormonal Contraseption & 2.93 & 0.23 & $<0.001$ \\
The age of 30-35 years & 0.70 & 0.24 & $<0.001$ \\
N Observation $=149$ & & & \\
Adjusted R square $=52 \%$ & & & \\
\hline
\end{tabular}

Table 8 shows the adjusted $\mathrm{R}$ square value $=52.6 \%$, this indicates that the variability of the dependent variable that can be explained by the independent variable is $52.6 \%$ while the remaining $47.4 \%$ is explained by the variability of other variables outside the two independent variables examined.

The results of the linear regression equation are described as follows.
1. Injection (hormonal) contraception affects 2.93 of abnormal abnormal bleeding and is statistically significant $(\mathrm{p}<0.001)$.

2. Age affects 0.70 to abnormal uterine bleeding and is statistically significant $(\mathrm{p}<0.001)$.

Table 9 shows that the adjusted $\mathrm{R}$ square $=58.5 \%$, this indicates that the dependent variable variability that can be explained by the independent variable is 
$58.5 \%$ while the remaining $41.5 \%$ is explained by the variability of other variables outside the two independent variables studied.

The results of the linear regression equation can be described as follows.

1. Injectable (hormonal) contraception

Table 9. Variable linear regression results for age and hormonal contraception with body mass index for women of childbearing age

\begin{tabular}{lccc}
\hline \multicolumn{1}{c}{ Independent Variable } & b & SE & p \\
\hline Constant & 21.90 & 0.49 & $<0.001$ \\
Hormonal Contraseption & 5.75 & 0.54 & $<0.001$ \\
The age of 30-35 years & 5.05 & 0.55 & $<0.001$ \\
N Observation= 149 & & & \\
Adjusted R square $=58 \%$ & & &
\end{tabular}

\section{DISCUSSIONS}

1. The relationship between the effectiveness of injection contraceptive use and the quality of sexual life

Injection contraceptive was divided into two groups, namely the progestin group and the progestin group with estrogenpropionate mixture (Saifuddin, 2010). One of the side effects of using injection contraceptive was the change in libido or sexual drive. Symptoms of a decrease or increase in sexual drive (libido). The decreased libido was due to the effects of progesterone, especially those which contained 19-progression that caused a dry vaginal. However, psychological factors could also affect this occurrence. Increased or decreased libido was very subjectively, therefore, these symptoms must be monitored carefully to ensure that the client has decreased or increased libido. Changes in libido can also be influenced by psychological factors (Irianto, 2014).

The result of this study revealed that there was a meaningful relationship between the effect of injection contraceptive and the quality of sexual life among women in reproductive age in Jombang District, and the level of relationship was low. This relationship has a positive pattern, affects 5.75 against the body mass index (BMI) and is statistically significant ( $p$ $<0.001)$.

The older the age is, the bigger the amount of 5.05 to abnormal uterine bleeding. Statistically, the relationship was stated to be significant ( $\mathrm{p}<0.001)$. meaning that the long-term use of injection contraceptive could increase the sexual quality disorders. The use of hormonal contraception could lead to sexual dysfunction for its users due to the hormonecontent contained in it.

The use of hormonal contraceptives that contained a combination of both hormones, estrogen and progestin, or which contained only one of the hormones, has a significant role in the incidence of sexual dysfunction. However, the hormonal contraceptive use that contained a combination of both hormones was more significant in causing sexual dysfunction compared to hormonal contraception which only contained one hormone, this was in line with a study done by Saputra (2013) which stated that comparison of the sexual dysfunction incident according to FSFI scoring on IUD and hormonal acceptors at Rajabasa Bandar Lampung Health Center stated that there were significant differences in the incidence of sexual dysfunction of hormonal and IUD acceptors, where the incidence of hormonal acceptor sexual dysfunction was higher than IUD acceptors, and the incidence of hormonal sexual dysfunction was higher than IUD. 
From the results of the frequency distribution of sexual quality in women of reproductive age, it was found that women of reproductive age did not experience higher disorders than those who experienced disorders.Women in reproductive age who experience disorders of more than half of the study subjects used 3-month injection contraceptives, while less than half of the subjects used 1-month injection contraceptives. Therefore, it was concluded thatthe use of Depo Provera injection contraceptive which contained DMPA (Depo Medroxyprogesteron Acetate) and it was given in every three months could lead to sexual quality disorders, this was in accordance with a study done byBatlajery (2015) which stated thatthe largest presentation of sexual dysfunction occurred in women who used the contraceptive method of DMPA injection (3-month injection) compared to women who used non-DMPA contraceptive methods. According to Yunardi, et al. (2009) in a study done by Batlajery (2015) it was stated that DMPA injections only contained the progesterone hormone which has the main effect to prevent ovulation with high levels of progestin which would actively inhibit the LH (Luteinizing Hormone) surge. This would eventually lead to sexual dysfunction in the form of decreased libido and other sexual potentials.

\section{The relationship between the effectiveness of injection contra- ceptive use and body mass index}

One of the side effects of injection contraceptives was weight changes. The symptoms of the average weight gain for each year varies between $2.3-2.9 \mathrm{~kg}$ of weight gain, it was probably caused by the progesterone hormone which help to change the carbohydrates and sugar into fat, so that the fat under the skin increased. In addition, the progesterone hormone also increased the appetite and reduced physical activity (Irianto, 2014). The debate about the enhancement of weight as a result of continuous use of DMPA-IM, as well as increasing the amount of weight reported to increase over time, from about 1-2 kg after 1 year of utilization to 4-10 $\mathrm{kg}$ after a long utilization of around 3-5 years. According to $\mathrm{WHO}$, in investigating the side effects and the reasons for discontinuation of DMPA-IM, it was found that women gained an average of $1.9 \mathrm{~kg}$ in the first year of DMPA-IM use, and body weight was quoted as one of the main reasons for the discontinuing use of DMPA-IM. (Sari, 2015).

The result of this study found that there was a relationship between the effect of injection contraceptive use and body mass index among women in reproductive age with an adequate level of relationship. This relationship has a positive pattern, meaning that the long-term use of injection contraceptives would increase the body mass index for about $2.5 \mathrm{~kg}$ on average. The use of hormonal contraceptives could lead to various side effects, one of them was the change in body weightacceptor. This was caused by the progesterone hormone which facilitated the changes in carbohydrates and sugar into fat, so that the fat under the skin tissue increased.

Weight gain was one of the side effects that were often complained of by hormonal contraceptive acceptors, especially hormonal injection contraceptives of Depo Medroxy Progesterone Acetate Contraceptive. This study was consistent with a study by Sriwahyuni and Wahyuni (2009) which stated that there was no significant relationship between the duration of hormonal contraceptive use and weight gain. This mean that the long-term used of hormonal contraception could increase the body weight. From the results of the frequency distribution of body mass index in women of reproductive age, it was found 
that most of the women of reproductive age experienced weight gain, while a small proportion of the research subjects did not experience weight gain.

Women reproductive age who experienced weight gain usually used 3-month injection contraceptive than 1-month injection contraceptive, this study was consistent with a study by Sari (2015) which stated that DMPA hormonal injection contraceptives were the only hormonal contraception that was consistently associated with weight gain. A prospective study found that women who used Depo-Provera gained an average weight of $5.1 \mathrm{~kg}$ for 36 months, while women who used combined oral contraceptives did not gain any weight.

\section{The relationship between the} effectiveness of injection contraceptive use and skin health

Injection contraceptive was divided into two groups: progestins and progestins with esterogenpropionate mixtures (Saifuddin, 2010). One of the side effects of using injection contraceptive was acne changes. The cause of acne was an enhancement in fat levels in Norprogestin-19 and the cause of weight gain occurred due to the progesterone hormone which help the process of changing the carbohydrates and sugar into fat, so that the fat under the skin increased (Irianto, 2014).

According to Suyono (2002) in Asva (2015), physiological amounts of progesterone have no effect on the effectiveness of the fat glands. Sebum production remained during the menstrual cycle, but sometimes progesterone could cause premenstrual acne.

The result of this study found that there was a relationship between the effect of injection contraceptive use and women's skin health with a low level of relationship. This relationship has a positive pattern, meaning that the long-term use of injection contraceptive would cause the occurrence of acne on the skin. The effect of injection contraceptives on skin health lead to the occurrence of acne vulgaris (acne).

Acne vulgaris (acne) was caused by estrogen and progesterone. Estrogen has no effect on sebum production. Estrogen could reduce the gonadotropin levels from the pituitary gland. The gonadotropin hormone has the effect of reducing sebum production, whereas sebum was an oily substance that mainly consisted of fat, keratin, and cellular ingredients produced by sebaceous glands in the skin. Physiologically, it has no effect on the effectiveness of the fat glands in progesterone. Sebum production remained during the menstrual cycle, but sometimes progesterone could cause premenstrual acne.

This study was consistent with a study by Kansil (2015) which stated that there was a relationship between injection contraceptive use ofdepo medroksi progesteron Asetat (DMPA) on physiological changesof WRA in Ranomuut health center, Manado. There was a relationship between DMPA injection contraceptive andphysiological changes such as body weight enhancement, acnes, and headaches among women reproductive age at Ranomuut Health Center in Manado.

From the result of frequency distribution, it was known thatmore than half of the study subjects did not have acne and less than half of the research subjects had acne. Women of reproductive age who used injection contraceptive for 3 months were more likely to have acne compared to women of reproductive age who used injection contraceptive for 1 month. Therefore, more than half of women in reproductive age who experienced acne used 3-month injection contraceptive.

Depo Provera content which contained DMPA (Depo Medroxyprogesterone 
Acetate) given once in every 3 months could give the side effects of acne, this was in line withRahmawati and Sukanto (2012) who stated thatthe progestins contained in oral contraceptives include estranges and gonanes which were derivatived of 19-nortestosterone, cyproterone acetate, the latest progestin, and drosperinone. Estrane groups (norethindrone, noretindron asetat, etinodiol diasetat) and gonane (norgestrel, levonorgestrel, desogestrel, gestoden, norgestimate) could increase the effect of androgenic and stimulated the occurrence of acne, hirsutism, and androgenic alopecia. This progestin could also lead to changes in lipid metabolism and could increase serum glucose.

While according to a study done by Maria, et al., (2016) it was stated that acne side effect could also be caused by the maternal diet which did not pay much attention to the consumption of foods that contained lots of fat. In addition, it can also be caused by improper use of cosmetics or cosmetic allergies.

\section{The relationship between the effectiveness of injection contra- ceptive use and abnormal uterine bleeding}

Side effects of injection contraceptive include menstrual cycle disorders. The symptoms or complaints including not having menstruation (amenorrhea), bleeding in the form of droplets or patches (spotting), bleeding outside the menstrual cycle (metroragia), longer and/or more than usual menstrual bleeding. The cause was due to hormonal imbalances so that the endometrium experienced histological changes, the condition of amenorrhea was caused by endometrial atrophy (Irianto, 2014). Bleeding from the corpus uteri include all menstrual abnormalities in terms of both number and duration. This was described as chronic if it was happened for the majority of the previous 6 months, and acute if it was a severe bleeding which required rapid treatment or intervention. Clinical manifestations could be in a condition of enormous bleeding, a little bleeding, an extended or irregular menstrual cycle (Bazaid et al., 2011).

The result of this study revealed that there was a relationship between the effect ofinjection contraceptive use and abnormal uterine bleeding among women in reproductive agewith a strong level of relationship. This relationship was positive, it mean that the long-term use of injection contraceptives would increase the incidence of abnormal uterine bleeding. Bleeding due to injection contraceptive use could occur in combined contraceptive pills (CCP) users, injections of depo medroxy progesterone acetate (DMPA). Bleeding in CCP users and DMPA injections mostly occurred due to interrupted bleeding.

This was in line with a study done by Monica and Mary (2016) which stated that subcutaneous DMPA and DMPA intramuscular injection also showed the similar effect beside body weight and changes in bleeding pattern, while a study of Firoozeh and Maryam (2013) stated that women aged 18-40 years old used Depo-Medroxy progesterone acetate (DMPA) or Cyclofem. One of the DMPA side effects was irregular bleeding, and the side effect in the Cyclofem group was also irregular bleeding. Bleeding pattern changes were the most important problem that lead to the second termination of contraceptive methods in participants.

From the result of frequency distribution, it was known that from the abnormal uterine bleeding, it can be concluded that menstrual bleeding with 2 pads of blood occurred outside the cycle for $<7$ days and $>12$ days. This was in line with a study done by Nelson (2010) which stated thatthe 
users of levonorgestrel intrauterine system decreased to $30 \mathrm{ml}$ of blood loss, whereas those who used medroxyprogesterone acetate achieved a reduction to $136 \mathrm{ml}$. The effectiveness of each therapy continued to increase over time. At the closing of the study at 6 months, median menstrual blood loss in women who used the levonorgestrel intrauterine system was only $7 \mathrm{ml}$, whereas in women who used medroxyprogesterone acetate was $121 \mathrm{ml}$.

\section{The relationship between injection contraceptive use, age, employment, and activity with sexual life}

Analysis of the relationship between independent variables of the use of injection contraceptives effectiveness, age, employment, and length of activity with sexual life on women of reproductive age by using linear regression test showed that one of the the four variables which related to sexual life of women in reproductive age was age. Age variables in women of reproductive age have a significant relationship which mean that the increased age of women reproductive age would affect the sexual life.

This study was consistent with a study by Batlajery (2015), which stated that women who have the reproductive organs which were functioned properly were around the ages of 20-45 years old. Over the age of 50 years old, there can be problems in sexual activity because they were getting older, got more work, and even various diseases such as high blood pressure, diabetes, reduced libido or impotence (Manuaba, 2009).

The frequency of sexual activity (coitus) was widely varied on average of 1-4 times a week for people aged 30-40 years old. Coitus became increasingly rare with the enhancement of age. In women, the libido increased in the reproductive period until the age of 35 years old, then it stayed until the age of 45 years old, and it could last after menopause. In men, the peak of libido was achieved at the age of 20-30 years old and the libido lasted until the age of 50 years old, and then it slowly reduced, but it remained in the body until they became elderly (Irianto, 2014).

\section{The relationship between injection contraceptive use, age, and educatio with body mass index}

Analysis of the relationship between independent variables of the use of injection contraceptives effectiveness, age, and education withbody mass indexamong women in reproductive age by using linear regression test showed that the variables which related to body mass index in women of reproductive age were the effectiveness of injection contraceptive use and education. Education variable has a significant relationship by 0.512 , which mean that the increased women education would affect the enhancement of body mass index. Weight gain in the study was largely due to hormonal in injection contraceptived, so the long-term use of injection contraceptive has the potential to increase body weight.

According to Sriwahyuni (2012), the use of hormonal contraceptives which were the most widely used by study subjects at every level of education was injection. The use of pills and implants was most widely used by research subjects in a high school education level. Knowledge about contraceptive methods has an impact on the selection of contraception types so that it indirectly influenced the behavior of the user.

The effectiveness of injection contraceptive use variable has a significant relationship. This mean that the effectiveness of long-term use of injection contraceptive in women of reproductive age would increase the body mass index. This was in line with a study done by Kansil (2015) 
which stated that there was an effect of The duration of Depo Provera injection contraceptives use on the side effects of weight gain. In addition, the progesterone hormone also caused appetite enhancement and decreased physical activity, therefore, the use of injections could lead to weight gain (Irianto, 2014; Sari, 2015).

\section{The relationship between injection contraceptive use and age with skin health}

Analysis of the relationship between independent variables with gross motor skills among toddlers by using logistic regression test showed that there was no statistically significant relationship between the effectiveness of the use of short-term injection contraceptives and skin health of acne occurrence.

This study was not consistent with a study by Suyono (2002) in Asva (2015), which stated that one of the causes of acne occurrence in skin health was progesterone. Progesterone, in physiological amounts has no effect on the effectiveness of fat glands. Sebum production remained during the menstrual cycle, but sometimes progesterone could cause pre-menstrual acne. In addition, the result of this study was not in line with a study done by Kansil (2015) which stated that there was a relationship between DMPA injection contraceptive and physiological changes such as increased weight, acne, and headaches in women of reproductive age.

\section{The relationship between injection contraceptive use, employment, and activity with abnormal uterine bleeding}

Analysis of the relationship between injection contraceptives use, employment, and the activity with abnormal uterine bleeding among women in reproductive ageby using linear regression test. It was found that the variables which associated with abnormal uterine bleeding in women of reproductive age were the effectiveness of injection contraceptive use and age. Age variable in women of reproductive age has a significant relationship by of 0.41 , which mean that the increased age of women in reproductive age would affect abnormal uterine bleeding. However, in this study, there was a variable that caused abnormal uterine bleeding, namely the effectiveness of the use of injection contraceptives. From the results of data analysis, the effectiveness of injection contraceptive use variable has a significant relationship by 0.91, which mean that the effectiveness of long-term use of injection contraceptive in women of reproductive age would affect abnormal uterine bleeding.

This was in line with Rifki (2016) and Bazaid et al. (2011) who stated that bleeding due to counter-septic side effects could occur in combined contraceptive pills (CCP) users, and injections of depo medroxy progesterone acetate (DMPA). Bleeding in CCP users and DMPA injections mostly occurred due to interrupted bleeding. Chlamydia or Neisseria infections could also cause bleeding in CCP users.

The results of this study can be concluded that there was an effect of injection contraceptive use on sexual life, body mass index, skin health, and abnormal uterine bleeding in women of reproductive age. The results of this study can be used to improve understanding of the side effects caused by long-term use of injection contraceptives, such as the sexual quality of the partner, body mass index, and skin health. Therefore, people can choose the appropriate contraceptive method.

\footnotetext{
REFERENCES

Almatsier (2011). Gizi dalam daur kehidupan. Jakarta: Gramedia.
} 
Anurogo (2012). Ejakulasi dini. Fakultas Kedokteran Universitas Palangka Raya / RS PKU Muhammadiyah Palangka Raya, Kalimantan Tengah, Indonesia.

Asva (2015). Mengetahui penyakit acne vulgaris (jerawat) dan penyebab penyakit acne vulgaris (jerawat). http://www.Dokterkreatif.com/2015/05/mengeta hui-penyakit-akne-vulgaris-jerawatdan-penyebab-akne-vulgaris-jerawat.

Batlajery J, Hamidah $\mathrm{H}$, Mardiana M (2015). Penggunaan metode kontrasepsi suntikan DMPA berhubungan dengan disfungsi seksual wanita pada akseptor KB suntik. Jurnal Ilmu dan Teknologi Kesehatan, 2(2).

Bazaid (2011). Panduan tata laksana perdarahan uterus abnormal. Jakarta: HUFERI - POGI

BKKBN (2011). Kamus istilah kependudukan dan keluarga berencana. Jakarta: Direktorat Teknologi Informasi dan Dokumentasi Badan Kependudukan dan Keluarga Berencana Nasional. (2013). Pemantauan pasangan usia subur melalui mini survei indonesia. Jakarta. BKKBN.

(2015). Pertumbuhan penduduk kita mengkhawatirkan. http://www.pikiranrakyat.com/nasional/2015/09/29/344178/pertumbuhan-penduduk-kita-mengkhawatirkan.

(2015). BKKBN Jatim: Penggunaan KB suntik diminati masyarakat. http://kominfo.jatimprov.go.id/read/ umum/bkkbn-jatim-penggunaan-kbsuntik-diminati-masyarakat.

BAPPENAS (2012). Bidang pembangunan sosial budaya dan kehidupan beragama. Jakarta: Badan Perencanaan Pembangunan Nasional.

Dahlan MS (2009). Statistik untuk kedokteran dan kesehatan. Jakarta: Salemba Medika.
Dragoman MV, Gaffield ME (2016). The safety of subcutaneously administered depot medroxyprogesterone acetate (104 mg/0.65 mL): A systematic review. Contraception, 94: 202-215. http://dx.doi.org/10.1016/j.contracep tion.2016.02.003.

Everett (2008). Buku saku: Kontrasepsi dan kesehatan seksual reproduktif. Jakarta: EGC.

Ghozali (2011). Aplikasi analisis multivariate dengan program IBM SPSS 19 (edisi kelima). Semarang: Universitas Diponegoro.

Harjanto BD, Indrawati L, Sari W (2012). Panduan lengkap kesehatan wanita. Jakarta: Penebar Plus.Irianto (2014). Pelayanan keluarga berencana dua anak cukup. Bandung: Alfabeta.

Hastono (2009). Statistik kesehatan. Jakarta : Rajawali Press.

(2014). Seksologi kesehatan. Bandung: Alfabeta.

Kansil SE, Kundre R, Bataha Y (2015). Hubungan penggunaan kontrasepsi suntik Depo Medroksi Progesteron Asetat (DMPA) dengan perubahan fisiologis pada Wanita Usia Subur (WUS) di Puskesmas Ranomuut Kota Manado. e-Journal Keperawatan, 3(3).

Magas MM, Kundre R, Masi G (2016). Perbedaan siklus menstruasi ibu pengguna kontrasepsi suntik cyclofem dengan depo medroxy progesterone asetat di wilayah kerja puskesmas Bontang Utara 1. e-journal Keperawatan, 4(1).

Murniawati E (2012). KB suntik 3 (tiga) bulan dengan efek samping gangguan haiddan penanganannya. Jurnal Staf Pengajar Kebidanan FK Unissula Semarang.

Murti B (2010). Desain dan ukuran sampel untuk penelitian kuantitatif dan kuali- 
tatif di bidang kesehatan. Yogyakarta: Gadjah Mada University Press.

Mahmud (2011). Metode penelitian pendidikan. Bandung: Pustaka Setia.

Nelson (2010). Levonorgestrel intrauterine system: a first-line medical treatment for heavy menstrual bleeding. Women's Health. 6(3): 347-356.

Ozgoli (2013). Comparison of sexual dysfunction in women using DepoMedroxyprogesterone Acetate (DMPA) and Cyclofem. J Reprod Infertil. 16(2): 102-108.

Proverawati I, Aspuah (2010). Panduan memilih kontrasepsi. Yogyakarta: Nuha Medika.

Pinem (2009). Kesehatan reproduksi dan kontrasepsi. Jakarta: TIM

Prasetyawati (2012). Kesehatan Ibu dan Anak (KIA) dalam Millenium Development Goals (MDGs). Yogyakarta: Nuha Medika.

Riduwan (2010). Metode dan teknik menyusui tesis. Bandung: Alfabeta.

Rahmawati, Sukanto (2012). Terapi hormonal pada akne vulgaris (Hormonal Therapy for Acne Vulgaris). Telaah Kepustakaan. Fakultas Kedokteran Universitas Airlangga/Rumah Sakit Umum Daerah Dr. Soetomo Surabaya, 24(1).

Rifki M, Loho M, Wagey FMM (2016). Profil perdarahan uterus abnormal di RSUP Prof. Dr. R. D. Kandou Manado periode 1 Januari 2013 - 31 Desember 2014. Jurnal e-Clinic (eCl), 4(1).

Rosen R, Brown C, Heiman J, Leiblum S, Meston C, Shabsigh R, Ferguson D, D'Agostino R Jr (2005). The Female Sexual Function Index (FSFI): A multidimensional self-report instrument for the assessment of female sexual function. Journal of Sex and Marital Therapy. 26(2): 191-208. Doi: 10.1080/009262300278597 .
Sukarni W (2013). Buku ajar: keperawatan maternitas. Yogyakarta: Nuha Medika.

Saifuddin (2010). Buku panduan praktis pelayanan kontrasepsi. Edisi 2. Jakarta: PT. Bina Pustaka Sarwono Prawirohardjo.

Sari IRN (2015). Kontrasepsi hormonal suntik Depo Medroxyprogesterone Acetate (DMPA) sebagai salah satu penyebab kenaikan berat badan. Jurnal Fakultas Kedokteran, Universitas Lampung. 4(7).

Saputra (2013). Perbandingan angka kejadian disfungai seksual menurut skoring FSFIpada Akseptor IUD dan hormonal di puskesmas Rajabasa Bandar Lampung. Jurnal Fakultas Kedokteran Lampung, 1(2).

Sriwahyuni, Wahyuni (2009). Hubungan antara jenis dan lama pemakaian alat kontrasepsi hormonal dengan peningkatan berat badan akseptor. The Indonesian Journal of Public Health, 8(3).

Saryono, Anggraeni (2013). Metodologi penelitian kualitatif dan kuantitatif. Yogyakarta: Nuha Medika.

Tarwoto, Wartonah (2011). Kebutuhan dasar manusia dan proses keperawatan. Jakarta: Salemba Medika.

Theresia (2013). Acne vulgaris. Erha Clinic \& Erha Apothecary, Kelapa Gading, Jakarta.

Uliyah (2010). Panduan aman dan sehat memilih alat KB. Yogyakarta: Insania.

Veisi F, Zangeneh M (2013). Comparison of two different injectable contraceptive methods: Depomedroxy Progesterone Acetate (DMPA) and cyclofem. Journal Family Reprod Health. 7(3): 109-113.

Wahyuningsih (2009). Dasar-dasar ilmu kesehatan masyarakat dalam kebidanan. Yogyakarta: Fitramaya. 
Journal of Maternal and Child Health 2016, 1(3): 146-16o

https://doi.org/10.26911/thejmch.2016.01.03.02

Zettira Z, Berawi KN (2015). Analisis hubungan penggunaan kontrasepsi hormonal dengan disfungsi seksual pada wanita. Jurnal Fakultas Kedokteran, Universitas Lampung, 4(7). 